B.C.'s Future in Forest Products Trade in Asia and the Pacific Area On Feb. 19, 24 speakers and more than 70 representatives of Industry, University, and Government met at U.B.C. to discuss B.C.'s future in forest products trade. Out-of-Province speakers were: Dr. L. Z. Rousseau, who outlined past development and future plans of the Dept. of Forestry; Dr. D. A. Wilson, who suggested what Government could do to improve trade; Mr. Paul Jones, who explained the role of the Dept. of Trade and Commerce in trade promotion; Dr. Stuart Rich, who warned of the battles ahead to keep wood's traditional markets; Dr. Carl Newport, who previewed the Timber Resources Review of the U.S. Forest Service which is to be published on March 1; Dr. S. D. Richardson, who told of his impressions about Communist China's trade potential; and Mr. J. C. Westoby, who gave an international perspective on B.C.'s future.

Mr. Westoby, Assistant Director, Forestry and Forest Products Div., FAO, Rome, came to Vancouver to deliver an H. R. MacMillan Lecture in Forestry at U.B.C. on Feb. 16. His lecture on World forest development: markets, men, and methods will be published. The proceedings of the seminar may also be published and enquiries should be directed to Mr. T. Matthews, Extension Dept., University of B.C.

\title{
New DEAN AT UBC
}

Dr. J. A. F. Gardner, a wood chemist, was appointed Dean of the U.B.C. Faculty of Forestry on Feb. 1, 1965. He took over from Dr. R. W. Wellwood who had served as Acting Dean since July, 1964 when Dean T. G. Wright rejoined Canadian Forest Products Ltd. Dr. Gardner has gained an international reputation for his research in wood chemistry. His work as Superintendent of the Vancouver Laboratory of the Forest Products Research Branch, Dept. of Forestry, was widely respected by representatives of Industry, Government, and University in B.C. Dr. Gardner will spend March, April, and May, 1965 in Australia and New Zealand, advising on research programs and touring research stations and Universities.

Planning for a new Forestry-Agriculture building, to be occupied in 1966, is well under way. If President J. B. Macdonald's views of the need to expand graduate work and research in forest science and forestry are followed through, planning will have to start soon for a new wing on the new building.

\section{National System Of Evaluating Land Capability For Forestry} Adopted For ARDA Use At Ottawa Meeting

The following introductory remarks made on Jan. 27 by Dr. L. $Z$. Rousseau, Deputy Minister of Forestry, are presented here because they present an excellent view of the need for the system and of the responsibilities to be faced by foresters in management of wildland resources.

"I am very pleased to welcome you here on behalf of the Department, and I am particularly pleased to learn that the result of your deliberations will be a national system of evaluating land capability for forestry.

To me this is a significant occasion in the history of forestry in Canada, as it is the first time in which the experts in this field from all of Canada have been assembled in one place to deal specifically with forest soils and land classification. There have been many regional meetings of this nature 
but, insofar as $\mathrm{I}$ am aware, this is the first time that provincial experts from Newfoundland to British Columbia, from the University Forestry Faculties, and our own Regional Offices, have been assembled to discuss their work.

For this, ARDA, the sponsoring agency, deserves a great deal of credit. I would like to point out that the Canada Land Inventory program represents a new concept in land management in Canada, in that it proposes to provide financial support to the provinces for a technical capability classification of all lands within the agricultural and fringe areas of Canada. For the first time we, as land planners, will have a proper technical base with which to work. It may be argued that this should have been done many years ago, and thereby avoid many of the mistakes of land settlement. This is true; however, we have to start somewhere, and in my opinion the need still exists in order to avoid further costly errors.

Regardless of our affiliations we, as Foresters, must wholeheartedly support this Canada Land Inventory by approving a national system and providing the capability classification of lands for forestry. If we do not, then it may be done by other organizations or disciplines much less competent to do so. I am aware that the greatest limiting factor to the execution of the program is a shortage of trained personnel. However, I feel that with the experienced Provincial, Federal and University personnel involving themselves in the forest land capapility program, an excellent nucleus exists to train new men in the disciplines of land classification. Furthermore, the universities have a major responsibility to provide the type of course training necessary for this work, and the ARDA program should stimulate action in this regard.

Pertinent to the thinking of this group, but more basic, perhaps, than the forest land capability program under discussion, is the consideration of the Foresters role in land management. In my opinion the Forester must ultimately accept the responsibility for the management of wild, that is, non-agricultural land, for all its multiple uses. Such uses as precipitation control, wildlife and recreation, can be complementary to its forest use capability and need not be an alternative. We are aware that the forest cover can be managed in such a way as to increase the water production, food for wildlife, and improve recreational amenities.

The forestry profession is not likely to be given the mandate for wildland management unless they demonstrate a willingness and capability to carry it out. Basic to land management for any purpose, but particularly the management of a forest crop, is a classification of these lands as to their physical properties and capability. It is almost inconceivable that we have been trying to manage forests in Canada for fifty years without having any knowledge of the growing medium.

Jurisdictional rights of the provinces over resources prevents the Federal Department of Forestry from mapping the characteristics of large areas of forest land unless the provinces request us to do so. Nevertheless, the Federal Government has a responsibility, through research, to perfect techniques and methods of classifying forest lands and of encouraging the provinces, in the national interest, to classify their lands.

The Research Branch of this Department has acknowledged this responsibility and has begun, with the financial assistance of ARDA, to add to its competent staff of forest soils men; initially these men will provide technical assistance 
to the provinces for the forest land capability program of ARDA, and in this regard we would hope that their abilities are properly and fully utilized. We also envisage an expanded program of forest soils classification in which the Provincial and the Federal Governments will, jointly or co-operatively, undertake the mapping of significant areas of forest land so that the techniques and methods will be perfected and a start will be made on the vast job ahead of us.

One item of the Agenda for this meeting will be the discussion of the necessity for a continuing committee to revise, as necessary, the national system of forest land capability. I would recommend that you also consider this committee as an instrument to investigate the possibilities of and report on a national system of forest soils classification. Thus it could be consulted as a National Forest Soils Committee whose duties would be to act as an advisory committee to this Department.

In this talk I have attempted to point out to you the importance this Department attaches to forest land classification. However, our immediate goal, and the purpose of this meeting, is to finalize a national system of forest land capability. I would recommend that we demonstrate our capability and interest in this important field by agreeing on a national system and thereafter supporting the forest capability classification of the Canada Land Inventory of ARDA.

If this meeting achieves this result, I think you will agree that we will have made a significant advance towards our major objective, that of classifying all forest lands."

Mr. R. J. McCormack was Chairman of the two day meeting. He will be distributing a detailed report to those concerned. The following points may be of general interest. The system is concerned with the capability of forest land to grow wood rather than with existing productivity at time of classification. Therefore, the concept of normality or yields of well stocked stands rather than average or empirical yields will be used in measuring capability. Seven classes are acceptable and can be subdivided as required. The classes are $0-10,11-30,31-50,51-70,71-90,91-110$, and more than 111 , cubic feet of mean annual increment of wood measured inside bark as gross merchantable volume in trees 4 inches $\mathrm{dbh}$ and larger, excluding intermediate yields from thinning. Classes of similar land recognizable on aerial photographs will be described by capability class, species or species groups, and a maximum of three factors which limit growth. Landform, parent material, drainage, and vegetation factors recognizable on aerial photos will be used in the primary stratification. It is hoped that these strata will also be useful for evaluation of capability for recreation and wildlife management. The minimum type size will be $1 / 2$-inch square at 1:50,000 and 1-inch square at 1:250,000. Mapping will be done by the provinces to meet standards discussed first at regional and then at this national conference. Summary will be done within two years by a computer mapping technique. The delegates to the meeting favoured establishment of an Advisory Committee with representatives from Government, Universities, and Industry. The maps will be used for planning of improvements under ARDA programs, which are aimed at reducing and, hopefully, eventually eliminating rural poverty in Canada.

J. H. G. SMITH 